\title{
Prevention of thromboembolic events in patients with atrial fibrillation - new anticoagulants
}

\author{
Prevenção de eventos tromboembólicos em portadores de fibrilação atrial - novos anticoagulantes
}

\author{
Alexandre Holthausen Campos ${ }^{1}$, Cláudio Cirenza ${ }^{2}$
}

\begin{abstract}
The authors present alternatives for the treatment of cardiac arrhythmias. Its detection is based on the use of different methods that record the cardiac electrical activity. The treatment involves intervening in the underlying disorder, antiarrhythmic drugs, stimulation and cardiac defibrillation devices, and, less often, surgery. The technological advances in the last two decades have provided greater efficiency in diagnoses and therapy. Atrial fibrilation patients will benefit from a new set of anticoagulant drugs tested in the past three years. The potential advantages include greater safety and efficacy, as well as convenience for not requiring frequent laboratory controls.
\end{abstract}

Keywords: Arrythmias, cardiac/ prevention \& control; Atrial fibrillation/ drug therapy; Anticoagulants/ therapeuthic use

\section{RESUMO}

Os autores apresentam as alternativas terapêuticas para 0 tratamento das arritmias cardíacas. Sua detecção baseia-se no uso de diferentes métodos de registro da atividade elétrica cardíaca. 0 tratamento envolve intervenção sobre o distúrbio de base, drogas antiarrítmicas, dispositivos de estimulação e desfibrilação cardíaca e, em casos infrequentes, cirurgia. Avanços tecnológicos nas últimas duas décadas têm propiciado maior eficiência diagnóstica e terapêutica nesse campo. Pacientes portadores de fibrilação atrial vão se beneficiar de um novo conjunto de drogas anticoagulantes testadas nos últimos 3 anos. As vantagens potenciais incluem maior segurança e eficácia, assim como comodidade por dispensarem controles laboratoriais frequentes.

Descritores: Arritmias cardíacas/ prevenção \& controle; Fibrilação atrial/ quimioterapia; Anticoagulantes/ uso terapêutico

\section{INTRODUCTION}

Cardiac arrhythmias occur as a primary manifestation, secondary to other heart diseases (cardiomyopathies, ischemia, etc.) or to systemic disorders, such as drugs, sepsis, hydroelectrolytic disorders, thyroid diseases, among others ${ }^{(1)}$. Although benign in most cases, arrhythmias are associated to poorer quality of life and hospital admissions, as well as to increased mortality of the general population and particularly of cardiac patients $^{(1)}$. Detecting arrhythmias is based on the use of different methods - invasive or not - that record the cardiac electrical activity. The treatment involves intervening in the underlying disorder, antiarrhythmic drugs, stimulation and cardiac defibrillation devices, and, less often, surgery. The technological advances in the last two decades have provided greater efficiency in diagnoses and therapy. However there are still some gaps.

\section{Atrial fibrillation}

Atrial fibrillation (AF) is the most frequent sustained arrhythmia, associated to several heart and systemic conditions, and its prevalence increases with ageing ${ }^{(1-3)}$. Besides morbidity caused by symptoms, it represents a significantly higher risk of thromboembolic events and ischemic cerebral vascular accident (CVA) (ischemic stroke $)^{(4)}$. Its control involves reverting and maintaining sinus rhythm through chemical or electrical means or simple control of ventricular rate. Studies comparing rhythm control and heart rate concluded that mortality of both strategies are similar However, for any treatment chosen, it is evident that effective oral anticoagulation is the critical variable to reduce morbidity and mortality in the group of patients studied ${ }^{(5,6)}$. Hence, in a relatively large group of patients, long-term anticoagulation is mandatory.

The individuals at higher risk for thromboembolic events have already been identified in clinical trials

1 Instituto Israelita de Pesquisa Albert Einstein - IIPAE, São Paulo (SP), Brazil.

${ }^{2}$ Universidade Federal de São Paulo - UNIFESP, São Paulo (SP), Brazil.

Correspondence author: Alexandre Holthausen Campos - Avenida Albert Einstein, 627, 2SS, Bloco A - Morumbi - CEP 05651-901 - São Paulo (SP), Brasil - Tel.: 11 2151-0800 -

e-mail: holthausen@einstein.br

Conflicts of interest: None

Received: Jan 31, 2011 - Accepted: June 6, 2011 
and include those with heart failure, systemic arterial hypertension, diabetes mellitus, previous stroke and advanced age ${ }^{(1)}$. With better socioeconomic conditions in developing countries and worldwide changes in lifestyle (sedentarism, inappropriate diet and obesity, for example), the prevalence of AF increases, likewise that of comorbid diseases associated to thromboembolic events. For this reason, the importance of adequate anticoagulation is increasingly greater. Until recently the only oral anticoagulant drugs available in the market were coumarin derivatives. Although much experience has been gained in using these compounds, and their efficacy in comparison with placebo or acetylsalicylic acid in prevention of ischemic stroke has been been widely documented $^{(1)}$, their use involves periodical controls of prothrombin time; their action is affected by many drugs, alcohol or foods; their initiation of action is slow and the half-life is prolonged; and the interindividual response pattern is highly variable. All these lead to low compliance to treatment and ineffective (insufficient or excessive) anticoagulation, loosing the protective effect or inducing/facilitating bleeding, as a complication.

Some years ago a new alternative came to the market and it would overcome these setbacks. Ximelagatran, a direct thrombin inhibitor, was launched as an effective anticoagulant that required no laboratory controls and had a convenient dosing schedule. Nevertheless, hepatotoxicity observed after sales led to the drug being removed from the market in $2006^{(7)}$.

\section{Recent advances}

Connolly et al., in 2009, published a study testing the efficacy and safety of a new drug - dabigatran, another direct thrombin inhibitor ${ }^{(8)}$. This randomized clinical trial, with administration of warfarin in the control group, was partially blind (since warfarin users required laboratory monitoring) and assessed two different schedules of dabigatran (110 or $150 \mathrm{mg}$, twice a day). The results demonstrated that the test drug and warfarin had similar efficacy, with lower risk of bleeding at the lower dose. Moreover, as compared to the control group, dabigatran at the higher dose was more effective and and the risk of relevant bleeding was not significantly higher. The profile of adverse effects of dabigatran was considered acceptable and was not different from the control group, except for gastrointestinal disorders. This discovery brought a new possibility in management of AF patients. The Food and Drug Administration (FDA), agency that controls medications in the United States, approved selling the drug for this purpose (prevention of ischemic stroke associated to AF) in October 2010. Dabigatran was available in the Brazilian market in 2010 (for prevention of deep venous thrombosis/venous thromboembolism after orthopedic surgery) and, recently, in 2011, it was approved for use in AF. The high cost is still a limiting fact for more disseminated use of the drug. Furthermore, more frequent use will determine the real safety profile of this medication. But current data indicate that it is very positive to add dabigatran to the existing therapeutic armamentarium. In this line, the possibility of having other oral anticoagulant agents available in the market is worth mentioning. These direct inhibitors of activated factor $\mathrm{X}$ have a mechanism of action distinct from coumarins and dabigatran, and their efficacy and safety in preventing systemic thromboembolic events in AF patients have been recently demonstrated in diverse clinical trials. This group of agents comprises rivaroxaban, apixaban, edoxaban and otamixaban. The first was evaluated in a randomized trial and compared to warfarin, and not considered inferior to it regarding efficacy and safety ${ }^{(9)}$. Even better results were obtained with apixaban. A study published in August 2011 ${ }^{(10)}$ demonstrated that, as compared to warfarin, apixaban was equally effective in preventing ischemic stroke, but it was associated to less bleeding and lower mortality. Both rivaroxaban and apixaban have not been approved for clinical use by the FDA yet, except in research projects. However, the possibility of having both drugs, as well as dabigatran, shows that prevention of ischemic stroke is advancing rapidly. This is good news in a field of knowledge that recently had the frustrated expectation of including a new antiarrhythimic agent to treat AF. Dronedarone, an analogue of the classic amiodarone, with lower systemic toxicity potential, had its efficacy and safety tested in permanent AF patients and compared to a placebo. The drug had already been approved by the FDA for treating non-permanent AF as well as atrial flutter, and in the study PALLAS (stopped early), it was associated to increased mortality, stroke (CVA) and hospital admissions due to heart failure ${ }^{(11)}$. The final FDA analysis as to the use of dronedarone in different indications is expected.

In conclusion, AF patients will benefit from a new set of anticoagulant drugs tested in the past three years. The potential advantages include greater safety and efficacy, as well as convenience for not requiring frequent laboratory controls. Cost, profile of adverse effects not fully known, in addition to lack of familiarity of physicians with these new medicines (including how to revert anticoagulation, if indicated) are issues that should be considered when choosing the ideal drugs for AF patients and at high risk of embolic phenomena.

\section{REFERENCESS}

1. Fuster V, Rydén LE, Cannom DS, Crijns HJ, Curtis AB, Ellenbogen KA, Halperin JL, Le Heuzey JY, Kay GN, Lowe JE, Olsson SB, Prystowsky EN, Tamargo JL, Wann S, Smith SC Jr, Jacobs AK, Adams CD, Anderson JL, Antman EM, 
Halperin JL, Hunt SA, Nishimura R, Ornato JP, Page RL, Riegel B, Priori SG, Blanc JJ, Budaj A, Camm AJ, Dean V, Deckers JW, Despres C, Dickstein K, Lekakis J, McGregor K, Metra M, Morais J, Osterspey A, Tamargo JL, Zamorano JL; American College of Cardiology/American Heart Association Task Force on Practice Guidelines; European Society of Cardiology Committee for Practice Guidelines; European Heart Rhythm Association; Heart Rhythm Society. ACC/AHA/ESC 2006 Guidelines for the Management of Patients with Atrial Fibrillation: a report of the American College of Cardiology/American Heart Association Task Force on Practice Guidelines and the European Society of Cardiology Committee for Practice Guidelines (Writing Committee to Revise the 2001 Guidelines for the Management of Patients With Atrial Fibrillation): developed in collaboration with the European Heart Rhythm Association and the Heart Rhythm Society. Circulation. 2006;114(7):e257-354

2. Go AS, Hylek EM, Phillips KA, Chang Y, Henault LE, Selby JV, et al. Prevalence of diagnosed atrial fibrillation in adults: national implications for rhythm management and stroke prevention: the AnTicoagulation and Risk Factors in Atrial Fibrillation (ATRIA) Study. JAMA. 2001;285(18):2370-5.

3. Furberg CD, Psaty BM, Manolio TA, Gardin JM, Smith VE, Rautaharju PM. Prevalence of atrial fibrillation in elderly subjects (the Cardiovascular Health Study). Am J Cardiol. 1994;74(3):236-41.

4. Sherman DG, Kim SG, Boop BS, Corley SD, Dimarco JP, Hart RG, Haywood LJ, Hoyte K, Kaufman ES, Kim MH, Nasco E, Waldo AL; National Heart, Lung, and Blood Institute AFFIRM Investigators. Occurrence and characteristics of stroke events in the Atrial Fibrillation Follow-up Investigation of Sinus Rhythm Management (AFFIRM) Study. Arch Intern Med. 2005;165(10):1185-91

5. Wyse DG, Waldo AL, DiMarco JP, Domanski MJ, Rosenberg Y, Schron EB, Kellen JC, Greene HL, Mickel MC, Dalquist JE, Corley SD; Atrial Fibrillation Follow-up Investigation of Rhythm Management (AFFIRM) Investigators. A comparison of rate control and rhythm control in patients with atrial fibrillation (AFFIRM). N Engl J Med. 2002;347(23):1825-33.
6. Van Gelder IC, Hagens VE, Bosker HA, Kingma JH, Kamp 0, Kingma T, Said SA, Darmanata JI, Timmermans AJ, Tijssen JG, Crijns HJ; Rate Control versus Electrical Cardioversion for Persistent Atrial Fibrillation Study Group. A comparison of rate control ad rhythm control in patients with recurrent persistent atrial fibrillation. N Engl J Med. 2002;347(23):183440.

7. http://www.astrazeneca.com/Media/Press-releases/Article/20060214-AstraZeneca-Decides-to-Withdraw-Exanta). Consulta em 31/08/2011.

8. Connolly SJ, Ezekowitz MD, Yusuf S, Eikelboom J, Oldgren J, Parekh A, Pogue J, Reilly PA, Themeles E, Varrone J, Wang S, Alings M, Xavier D, Zhu J, Diaz $\mathrm{R}$, Lewis BS, Darius H, Diener HC, Joyner CD, Wallentin L; RE-LY Steering Committee and Investigators. Dabigatran versus warfarin in patients with atrial fibrillation. N Engl J Med. 2009;361(12):1139-51.

9. Patel MR, Mahaffey KW, Garg J, Pan G, Singer DE, Hacke W, Breithardt G, Halperin JL, Hankey GJ, Piccini JP, Becker RC, Nessel CC, Paolini JF, Berkowitz SD, Fox KA, Califf RM; the ROCKET AF Investigators. Rivaroxaban versus Warfarin in Nonvalvular Atrial Fibrillation. N Engl J Med. 2011 Aug 10. Epub ahead of print

10. Granger CB, Alexander JH, McMurray JJ, Lopes RD, Hylek EM, Hanna M, Al-Khalidi HR, Ansell J, Atar D, Avezum A, Bahit MC, Diaz R, Easton JD, Ezekowitz JA, Flaker G, Garcia D, Geraldes M, Gersh BJ, Golitsyn S, Goto S, Hermosillo AG, Hohnloser SH, Horowitz J, Mohan P, Jansky P, Lewis BS, Lopez-Sendon JL, Pais P, Parkhomenko A, Verheugt FW, Zhu J, Wallentin L; the ARISTOTLE Committees and Investigators. Apixaban versus Warfarin in Patients with Atrial Fibrillation. N Engl J Med. 2011 Aug 27. Epub ahead of print

11. Food and Drug Administration (FDA) [Internet]. FDA Drug Safety Communication: Multaq (dronedarone) and increased risk of death and serious cardiovascular adverse events. [cited 2011 Aug 31]. Available from: http://www.fda.gov/ Drugs/DrugSafety/ucm264059.htm 